\title{
The Effect of Metacognitive and Cognitive Writing Strategies on Iranian Elementary Learners' Writing Achievement
}

\author{
Amir Reza Nemat Tabrizi \\ Department of English Language, Payame Noor University, Iran \\ E-mail: arnemati@pnu.ac.ir \\ Mehran Rajaee (Corresponding author) \\ Department of English Language, Payame Noor University, Iran \\ E-mail: rajaeemehran@yahoo.com
}

Received: August 23, 2016 Accepted: September 25, 2016 Published: October 07, 2016 doi:10.5296/ijld.v6i3.9935 URL: http://dx.doi.org/10.5296/ ijld.v6i3. 9935

\begin{abstract}
Learners' strategy use has been widely researched over the past few decades. However, studies which focus on the impact of cognitive and metacognitive strategies on primary learners are somewhat rare. Therefore, the focus of this paper is to provide an experimental investigation to explore the effect of cognitive and metacognitive writing strategies on Iranian elementary learners' writing. To this end, 75 elementary learners were recruited to participate in this study. The findings show that the intervention achieved a significant treatment effect on both experimental groups including cognitive and metacognitive writing strategies groups. Furthermore, it was found that the metacognitive group outperformed the cognitive one.
\end{abstract}

Keywords: Metacognitive strategy, Cognitive strategy, Young learners, English writing, Achievement, Iran 


\section{Introduction}

Over the last few decades, writing strategies has attracted much attention (e.g. Bai, $\mathrm{Hu}, \& \mathrm{Gu}$, 2014; Chien, 2012; de Larios, Murphy, \& Manchon, 1999; De Silva, 2015; De Silva \& Graham, 2015; Hayes \& Flower, 1980) because of its importance as a way of communication. Clearly, attention to writing can be because of globalization, requirement of writing for school projects, and shift from product view to process one (chien, 2012; silva \& Brice, 2004).

In this regard, students should try to apply the appropriate strategies to be a successful and competent writer because a positive correlation can be found between strategy use and writing competence (Bai et al., 2014; Chien, 2012). So, the teachers should try to teach the strategies to students because as indicated by De Silva (2015), Hu (2005), Ong and Zhang (2013), and Wong and Hew (2010) strategy based introduction (SBI) can have positive effect on quantity and quality of EFL/ESL learners' use of writing strategy and their writing competence.

In spite of the effective role of writing strategies instruction on learners' writing achievement, review of the literature indicated the inadequacy of evaluating the effect of cognitive and metacognitive writing strategies on Iranian EFL elementary learners. Therefore, the present study seeks to investigate how EFL elementary learners' writing can be impacted by cognitive and metacognitive writing strategies. This paper also aimed at exploring if there could be any effect of both cognitive and metacognitive writing strategies, which strategy has better effect.

\section{Statement of the Problem}

Writing strategies have been studied over the latest few decades because as argued by Harris et al. (2008), learners have difficulties in writing with lack of knowledge in writing strategies. Although there were many researches about writing strategies, few of them have been carried out to examine how cognitive and metacognitive strategies can impact learners' writing.

Furthermore, there have been relatively few studies on Iranian EFL learners; however, Manchon (2009) indicated that different settings should be studied for L2 writers. Writing strategies should be taught to EFL learners because as AnaniSarab (2010) and Kiany and Movahedian (2012) noted, foreign language curriculum noticed more structures and forms and are more product rather than process oriented.

In addition, as a language teacher, some of the pupils have problem in writing when they are required to have writing activity because the strategies have not been taught to them when they were in primary levels. By the same token, Bai $(2015$, p. 97) proposed that "it is highly important to train students to write effectively from young". For this purpose, the present study attempts to examine the primary learners.

In a nutshell, the following gaps have been identified with regard to writing strategy researches. Firstly, how cognitive and metacognitive writing strategies can affect learners? Secondly, there is a lack of research into Iranian EFL learners. Finally, there has been little 
discussion on elementary learners. Therefore, in order to cover the highlighted problems, this study seeks to gauge the effect of cognitive and metacognitive writing strategies on EFL elementary learners' writing.

\section{Research Questions and Hypotheses}

Based on the problem mentioned above, this study tries to answer the following questions:

Q1: Does cognitive writing strategies have any significant effect on Iranian elementary learners' writing?

Q2: Does metacognitive writing strategies have any significant effect on Iranian elementary learners' writing?

Q3: In case of any effect, which of cognitive or metacognitive strategies have more effect on elementary learners' writing?

Based on the research questions, the following hypotheses are formulated:

H01: Cognitive writing strategies do not have any significant effect on Iranian elementary learners' writing.

H02: Metacognitive writing strategies do not have any significant effect on Iranian elementary learners' writing.

H03: Cognitive writing strategies have more effect on Iranian elementary learners' writing.

\section{Literature Review}

According to Oxford (1990), learning strategies can be divided into two broad types: direct and indirect strategies. Direct strategies can be classified into memory, cognitive, and compensation strategies which is directly connected with target language and language learning. Indirect strategies can be grouped into metacognitive, affective, and social strategies which do not directly affect the target language. According to Abdollahzadeh (2010, p.66), cognitive strategies concern with "the actual mental processes involved in developing a text while writing". In the literature, metacognitive strategies tend to be used to refer to executive strategies which can be utilized to control the students' learning process. It can be used to monitor, plan, and evaluate their process on learning (Brown, 1983; O'Malley \& Chamot 1990; Cohen, 1998)

Flower and Hayes (1981) proposed one of the early empirical studies of writing strategies to inspire other researchers and to react against controlled compositions. In this regard, a considerable amount of literature has been published on adult or young adult learners (e.g. Baker \& Boonkit 2004; Chen 2011; Chien, 2012; De Silva, 2015, De Silva \& Graham, 2015). These studies have attempted to contemplate writing strategies from different perspectives. For example, Chien (2012) noted writing strategies relationship with the students' English writing achievement in Taiwan. Forty students participated in this study divided into 20 low and 20 high achievers. High achieving students focused more on planning, composing, and reviewing, while low achieving students paid less attention. Moreover, word-level and 
discourse-level revisions were attended more by high achieving students. The last but not least point was that the teachers can greatly help the students to have more coherent thinking in writing.

In another study, De Silve (2015) attempted to show how writing strategies can impact SL writing. The results were attained from 72 students who enrolled for the bachelor of the science degree program. The studied strategies were planning, formulating, self monitoring, evaluation, and revision. And as the results demonstrated, the experimental group increase was higher than the control group. Moreover, strategy instruction can have positive impact on writing performance and the students should be trained to utilize writing strategies effectively.

More recently, De Silva \& Graham (2015) investigated that how strategy instruction can influence the students with different proficiency levels. They have worked on 72 students which were divided into control and experimental group. Eighteen of them were of high attainment and eighteen of them were of low attainment. The strategies which were worked on were categorized into task analysis, planning, formulating, self monitoring, evaluation, resourcing, and revision. In task analysis, planning, self monitoring, and evaluation the experimental group showed greater growth. The control group demonstrated increase in formulating strategy while the experimental group showed a decrease. For evaluation, the increase of both groups was equal. The control group benefited slightly more in resourcing.

A careful study of the literature reveals that young learners have not been thoroughly investigated. Bai (2015) and Bai et al. (2014) published two recent studies on primary learners. The study by Bai et al. (2014) focused on primary school students in Singapore to show the relationship between use of writing strategies and English proficiency. 1618 students from two schools participated in this study. And the metacognitive strategies, cognitive strategies, and social / affective strategies were instructed. In school 1, the top proficiency group was superior to the bottom proficiency group but was nearly equal to the middle proficiency group. In school 2, the top proficiency group was superior to the middle and low proficiency group. Also, the middle proficiency group was almost equal to the bottom proficiency group. Furthermore, a positive relationship could be seen between strategy use and language proficiency.

Bai (2015) studied on 442 primary students to see how writing strategy instruction can affect the students' writing. It was understood from quantitative and qualitative results that the students' awareness of strategy use, their strategy use, and their writing competence can be promoted by writing strategy instruction.

In recent years, there has been an increasing amount of literature on Iranian students demonstrating the importance of studying different domains of writing strategies on EFL learners (e.g. Abdollahzadeh, 2010; Anani Sarab \& Amini Faresani, 2014; Dehghan \& Razmjoo, 2012; Fahandezh Sadi \& Othman, 2012). More recently, Anani Sarab and Amini Faresani (2014) attempted to get the writing strategies relationship with the personality types in Iran. 224 male and female students who were the students of English at graduate level participated in this study. They studied metacognitive, cognitive, affective, and social 
strategies. The most and least frequently used strategies were metacognitive and cognitive strategies respectively. Furthermore, feeling and judging in personality types were related to writing strategies. Finally, it was mentioned that "the relationship between personality types and strategies is moderated by the context of teaching and learning" (p, 69).

Although the above investigations examined different viewpoints of writing strategy instruction to the best of author knowledge, only few reference in the literature systematically describe the effect of cognitive and metacognitive writing strategies on the elementary learners. This was the motivation behind the present study.

\section{Method}

\subsection{Participants}

The participants of the study were 75 EFL students (both male and female) who were randomly selected out of 100 with the age range of 10 to 14 from a total population of 150 students studying English at two private language institutes in Golestan, Iran. They were all native speakers of Persian. All 150 students received a standard version of Nelson test to make sure that the study enjoys homogeneous and identical participants with respect to the participants' English language proficiency. One hundred students who scored one standard deviation (1SD) above and below the mean were selected and the researcher could randomly select 75 participants from them. The participants of the study were also randomly divided into three groups to form two experimental groups (cognitive and metacognitive writing strategies) and one control group. The total number of students in experimental group was 50 ( 25 in each group). Furthermore, there were 25 participants in the control group.

\subsection{Instruments}

\subsubsection{Nelson test}

To make sure that the participants were all at the same level of language proficiency; namely, elementary level, Nelson English Language Test (Coe \& Fowler, 1976) was conducted. The test included 50 items. The test is designed for a $30(60 \%)$ pass mark. The reliability of the Test was calculated through KR-21 in a pilot study (0.84).

\subsubsection{Pre and Post-test Instruments}

The second and third instruments utilized in the study were a pretest and a posttest of writing employed from Family and Friends 3 book (Thumpson and Simmon, 2009). The writing tasks were checked for its content validity by two experts before it was given to the students.

\subsubsection{Writing Scoring Criteria}

Jacob's ESL composition profile (Jacobs, Zingraf, Wormuth, Hartfiel \& Hughey, 1981) will be occupied to analyze key aspects of writing. In this regard, five broad categories of rating including mechanics, language use, content, organization, and vocabulary were focused. The response scales will range from excellent to poor. The validity of scale is verified by a large number of raters and composition researchers. Then, in order to enhance the reliability scoring, the tasks will be rated by two raters (Farhadi, Ja'farpur, \& Birjandi, 2010) and if the 


\section{Macrothink \\ International Journal of Learning and Development \\ ISSN 2164-4063 \\ 2016, Vol. 6, No. 3}

raters' given scores were different, the mean of the two scores will be computed.

\subsection{Procedure}

The first phase of this study involved the pilot phase during which 30 elementary students with similar features to the target sample took the sample Nelson employed to homogenize the participants. In the second phase of the study, the Nelson Test was administered to the total population. Then, 75 students, as the main participants of the study, were randomly selected out of 100 students whose scores fell one standard deviation (1SD) above and below the mean. The students were also randomly appointed to three groups, two experimental groups and one control group with 25 students in each of the three groups.

Then, the pre-test of writing was administered to all participants to assure the homogeneity of the subjects in three different groups prior the beginning of the study. In the next phase, the treatment period began and continued for 10 sessions. The learners in the control group received almost no specific training on the strategies of writing; however, they had the same number of teaching hours and followed the same course content. It was tried to keep the situation in all classes the same and the only focused difference was the instruction of the cognitive and metacognitive strategies in the experimental groups. Then, the post-test of writing was administered to check the learners' writing development. In this phase, both control and experimental groups were asked to take a writing test. Finally, the data was gathered and analyzed through SPSS version 16 and the results and findings were reported.

\section{Result}

\subsection{Pre test of Writing}

The descriptive statistics for the writing pre-test in both experimental groups and control group are detailed in Table 1 . The cognitive group $(\mathrm{M}=73.04, \mathrm{SD}=4.54)$ showed the highest mean on the pretest of writing. This was followed by the control $(\mathrm{M}=72.88, \mathrm{SD}=$ 4.68) and metacognitive $(\mathrm{M}=72.48, \mathrm{SD}=4.29)$ groups. 
Table 1. Descriptive Statistics, Pretest of Writing by Groups

\begin{tabular}{|c|c|c|c|c|c|c|c|c|}
\hline & \multirow[b]{2}{*}{$\mathrm{N}$} & \multirow[b]{2}{*}{ Mean } & \multirow[b]{2}{*}{$\begin{array}{l}\text { Std. } \\
\text { Deviation }\end{array}$} & \multirow[b]{2}{*}{$\begin{array}{l}\text { Std. } \\
\text { Error }\end{array}$} & \multicolumn{2}{|c|}{$\begin{array}{l}95 \% \text { Confidence Interval } \\
\text { for Mean }\end{array}$} & \multirow[b]{2}{*}{$\begin{array}{l}\text { Minimu } \\
\mathrm{m}\end{array}$} & \multirow[b]{2}{*}{$\begin{array}{l}\text { Maxim } \\
\text { um }\end{array}$} \\
\hline & & & & & $\begin{array}{l}\text { Lower } \\
\text { Bound }\end{array}$ & $\begin{array}{l}\text { Upper } \\
\text { Bound }\end{array}$ & & \\
\hline Control & 25 & 72.88 & 4.68 & .937 & 70.95 & 74.81 & 64 & 82 \\
\hline Cognitive & 25 & 73.04 & 4.54 & .908 & 71.17 & 74.91 & 64 & 82 \\
\hline $\begin{array}{l}\text { Metacognit } \\
\text { ive }\end{array}$ & 25 & 72.48 & 4.29 & .859 & 70.71 & 74.25 & 63 & 81 \\
\hline Total & 75 & 72.80 & 4.45 & .514 & 71.78 & 73.82 & 63 & 82 \\
\hline
\end{tabular}

As illustrated in table 2, there was no significant difference at the $\mathrm{P}>.05$ level in pretest writing scores for the three groups: $\mathrm{F}(2,72)=.102, \mathrm{P}=.9$. Thus, it can be concluded that they enjoyed the same level of writing ability prior to the main study.

Table 2. One way ANOVA on pre-test by groups

\begin{tabular}{|l|l|l|l|l|l|}
\hline \multicolumn{2}{|l|}{} & Sum of Squares & $\begin{array}{l}\text { Mean } \\
\text { Square }\end{array}$ & F & Sig. \\
\hline $\begin{array}{l}\text { Between } \\
\text { Groups }\end{array}$ & 4.160 & 2 & 2.080 & .102 & .903 \\
\hline $\begin{array}{l}\text { Within } \\
\text { Groups }\end{array}$ & 1463.840 & 72 & 20.331 & & \\
\hline Total & 1468.000 & 74 & & & \\
\hline
\end{tabular}

\subsection{Post test of writing}

A one-way ANOVA was run to compare the three groups' means on writing in order to probe the effects of different types of strategies on the improvement of their writing. As Table 3 indicates, the metacognitive strategy group $(\mathrm{M}=80.76, \mathrm{SD}=4.86)$ had the highest mean on the post-test of writing. This was followed by the cognitive strategy group $(\mathrm{M}=79.12, \mathrm{SD}=$ $6.38)$ and control group $(\mathrm{M}=74.88, \mathrm{SD}=4.29)$. 
Table 3. Descriptive Statistics; Posttest of Writing Achievement by Groups

\begin{tabular}{|c|c|c|c|c|c|c|c|c|}
\hline & \multirow[b]{2}{*}{$\mathrm{N}$} & \multirow[b]{2}{*}{ Mean } & \multirow[b]{2}{*}{$\begin{array}{l}\text { Std. } \\
\text { Deviation }\end{array}$} & \multirow[b]{2}{*}{$\begin{array}{l}\text { Std. } \\
\text { Error }\end{array}$} & \multicolumn{2}{|c|}{$\begin{array}{l}95 \% \text { Confidence Interval } \\
\text { for Mean }\end{array}$} & \multirow[b]{2}{*}{$\begin{array}{l}\text { Minimu } \\
\mathrm{m}\end{array}$} & \multirow[b]{2}{*}{$\begin{array}{l}\text { Maxim } \\
\text { um }\end{array}$} \\
\hline & & & & & $\begin{array}{l}\text { Lower } \\
\text { Bound }\end{array}$ & $\begin{array}{l}\text { Upper } \\
\text { Bound }\end{array}$ & & \\
\hline Control & 25 & 74.88 & 4.29 & .859 & 73.11 & 76.65 & 68 & 85 \\
\hline Cognitive & 25 & 79.12 & 6.38 & 1.276 & 76.49 & 81.75 & 68 & 91 \\
\hline $\begin{array}{l}\text { Metacognit } \\
\text { ive }\end{array}$ & 25 & 80.76 & 4.86 & .972 & 78.75 & 82.77 & 71 & 92 \\
\hline Total & 75 & 78.25 & 5.75 & .664 & 76.93 & 79.58 & 68 & 92 \\
\hline
\end{tabular}

Table 4 provides that there was a statistically significant difference at the $\mathrm{P}<.05$ level in post test writing scores for the three groups: $\mathrm{F}(2,72)=.8 .34, \mathrm{P}=.001$.

Table 4. One-Way ANOVA; Post-test of Writing Achievement by Groups

\begin{tabular}{|l|l|l|l|l|l|}
\hline \multicolumn{2}{|l|}{ Sum of Squares } & df & $\begin{array}{l}\text { Mean } \\
\text { Square }\end{array}$ & F & Sig. \\
\hline $\begin{array}{l}\text { Between } \\
\text { Groups }\end{array}$ & 460.347 & 2 & 230.173 & 8.345 & .001 \\
\hline $\begin{array}{l}\text { Within } \\
\text { Groups }\end{array}$ & 1985.840 & 72 & 27.581 & & \\
\hline Total & 2446.187 & 74 & & & \\
\hline
\end{tabular}

Post hoc comparisons using the Tukey HSD test, as demonstrated in table 5, indicated that firstly, the metacognitive strategy group $(M=80.76)$ significantly outperformed the control group $(\mathrm{M}=74.88)$ on the post-test of writing $(\mathrm{MD}=5.88, \mathrm{P}=.001<.05)$. Secondly, the cognitive strategy group $(M=79.12)$ surpassed the control group $(M=74.88)$ in the post-test of writing $(\mathrm{MD}=4.24, \mathrm{P}=.015<.05)$. Finally, the metacognitive strategy group $(\mathrm{M}=80.76)$ had better performance than the cognitive strategy group $(M=79.12)$ on the post-test of 
writing $(\mathrm{MD}=1.64, \mathrm{P}=.515>.05)$.

Table 5. Multiple Comparisons

\begin{tabular}{|c|c|c|c|c|c|c|}
\hline \multirow[b]{2}{*}{$\begin{array}{l}\text { (I) } \\
\text { Grouping }\end{array}$} & \multirow[b]{2}{*}{$\begin{array}{l}(\mathrm{J}) \\
\text { Grouping }\end{array}$} & \multirow{2}{*}{$\begin{array}{l}\text { Mean } \\
\text { Difference } \\
(\mathrm{I}-\mathrm{J})\end{array}$} & \multirow[b]{2}{*}{$\begin{array}{l}\text { Std. } \\
\text { Error }\end{array}$} & \multirow[b]{2}{*}{ Sig. } & \multicolumn{2}{|l|}{$\begin{array}{l}95 \% \\
\text { Interval }\end{array}$} \\
\hline & & & & & $\begin{array}{l}\text { Lower } \\
\text { Bound }\end{array}$ & $\begin{array}{l}\text { Upper } \\
\text { Bound }\end{array}$ \\
\hline \multirow[t]{2}{*}{ Control } & Cognitive & $-4.240^{*}$ & 1.485 & .015 & -7.79 & -.69 \\
\hline & $\begin{array}{l}\text { Metacognit } \\
\text { ive }\end{array}$ & $-5.880^{*}$ & 1.485 & .001 & -9.43 & -2.33 \\
\hline \multirow[t]{2}{*}{ Cognitive } & Control & $4.240^{*}$ & 1.485 & .015 & .69 & 7.79 \\
\hline & $\begin{array}{l}\text { Metacognit } \\
\text { ive }\end{array}$ & -1.640 & 1.485 & .515 & -5.19 & 1.91 \\
\hline \multirow{2}{*}{$\begin{array}{l}\text { Metacognit } \\
\text { ive }\end{array}$} & Control & $5.880^{*}$ & 1.485 & .001 & 2.33 & 9.43 \\
\hline & Cognitive & 1.640 & 1.485 & .515 & -1.91 & 5.19 \\
\hline
\end{tabular}

Taken together, these results suggest that the first two hypotheses are rejected because both cognitive and metacognitive strategies have significant effect on EFL primary learners. Moreover, the third hypothesis is also rejected because metacognitive strategy has more effects on Iranian elementary learners.

\section{Discussion and Conclusion}

In this section, the findings and discussion are organized around the research questions. With respect to the first and second research questions, it was found that the learners' scores in experimental groups have gone up which means the experimental groups' students have made progress after writing strategy instruction over the semester. These results corroborate the ideas of Bai (2015), De Silva (2015), Ong and Zhang (2013), and Wong and Hew (2010) who suggested that writing strategy instruction can help elementary learners to enhance the quality of their writing.

The observed increase in experimental groups' scores could be attributed to the theoretical basis of writing strategy instruction which lies in thinking-and-reasoning process of writing (Bereiter, Burtis, \& Scardamalia, 1988; Hayes \& Flower, 1980) and theories of learning highlighting the importance of self-regulation (Schunk \& Zimmerman, 1997; Zimmerman, 
2000). Another possible explanation, according to Bereiter and Scarmadalia (1987), Kellogg (1996), and Eysenack and Keane (2005) may be due to several skills and strategies including self-regulation skills, specific skills to the actual process of writing, and knowledge about writing which a good writer needs to learn and master in order to write better. Therefore, provided with right writing strategies, second language learners can become more autonomous learners and also can better perceive, assess, and improve their learning and writing (Bloom, 2008)

Regarding the third research question, the finding provides evidence that the metacognitive group was superior to the cognitive group. The results further support the idea of Abdollahzadeh (2010), Anani Sarab and Amini Faresani (2014), Yaghoubi (2003), and Riazi (1997) which concluded that Iranian learners of English as a foreign language take advantage of metacognitive strategy more than cognitive one.

It seems possible that the metacognitive strategy prominence is due to power of planning and power of integrating other strategies which the metacognitive strategy group learners achieved during the intervention. According to Bai et al. (2014) among the subscales of cognitive and metacognitive strategies, planning was the most frequently used strategy by the primary learners in Singapore. Study by Anderson (2003, p.25) also found that "being metacognitively aware of strategy use allows a writer to use strategies in an integrated way as opposed to thinking that they occur in isolation".

In summary, therefore, the present study was designed to determine the impact of cognitive and metacognitive strategies on Iranian elementary learners' writing ability. To this end, 75 elementary learners were recruited to form two experimental groups including cognitive and metacognitive strategies groups and one control group. This research has shown that both cognitive and metacognitive strategies can be effective and enhance the Iranian elementary learners' writing achievement. Furthermore, the most obvious finding to emerge from this study is that metacognitive group outperformed the cognitive one.

The present study has important contributions to writing strategy instruction research. It has been one of the few studies to explore the effect of writing strategy instruction on young writers in an EFL context. Moreover, it has been one of the few attempts to compare the learners' writing performances according to cognitive and metacognitive strategies instruction.

Having the findings at hand, two practical implications can be highlighted in this study. The first implication is for students. The findings of this study are helpful to students in demonstrating the importance of employing writing strategies to write better. Moreover, the outcomes of the study can contribute to materials and syllabus design to indicate which kind of strategies are most likely to be used by students.

It is a fact that no research is complete in its own right. Therefore, it is recommended that further research be undertaken in the following areas: Further experimental investigations based on larger corpora from different institutes are needed to contribute to the creation of more reliable research. Future research should also concentrate on the investigation of the 
effect of metacognitive and cognitive writing strategies on Iranian intermediate and advanced learners' writing achievement. Last but not least, the focus of the current research was on the EFL learners, so the other researchers can turn their attention to the ESL learners for new information.

\section{Acknowledgement}

The authors would like to thank the two anonymous reviewers and the editors for their helpful suggestions and comments during the preparation of this article. We would also like to thank Mahdi Najar and Zeinab Rajaee from Danesh English institute for their invaluable contribution to the study. Thanks also go to the students who participated in this study from Danesh English institute in Yasaqi, Golestan.

\section{References}

Abdollahzadeh, E. (2010). Undergraduate Iranian EFL learners' use of writing strategies. Writing and Pedagogy, 2(1), 65-90.

Anani Sarab, M. R. (2010). Secondary level foreign languages curriculum guide: Opportunities and challenges in its development and implementation. Journal of Educational Innovations, 9(35), 172-199.

Anani Sarab, M. R., \& Amini Faresani, M. (2014). The relationship between writing strategies and personality types of graduate Iranian EFL learners. Applied Research on English Language, 3(6), 69-84.

Anderson, N. J. (2003). Metacognition in writing: facilitating writer awareness. In A. Stubbs, \& J. Chapman (Eds.), Rhetoric, uncertainty, and the university as text: How students

construct the academic experience (pp. 10-30). Regina: Canadian Plains Research Center, University of Regina.

Baker, W., \& Boonkit, K. (2004). Learning strategies in reading and writing: EAP contexts. RELC, 35(3), 299-328.

Bai, B. (2015). The effects of strategy-based writing instruction in Singapore primary schools. System, 53, 96-106.

Bai, R., Hu, G., \& Gu, P. Y. (2014). The Relationship Between Use of Writing Strategies and English

Proficiency in Singapore Primary Schools. The Asia-Pacific Education Researcher, 23(3), 355-365.

Bereiter, C., Burtis, P. J., \& Scardamalia, M. (1988). Cognitive operations in constructing main points in written composition. Journal of Memory and Language, 27(3), 261-278. doi:10.1016/0749-596X(88)90054-X.

Bereiter, C., \& Scarmadalia, M. (1987). The psychology of written composition. Mahwah, NJ: 
Lawrence Erlbaum Associates.

Bloom, M. (2008). Second language composition in independent settings: Supporting the writing process with cognitive strategies. In S. Hurd \& T. Lewis (eds.), Language learning strategies in independent settings (pp. 103-118). Tonawanda, NY: Multilingual Matters.

Brown, A. L., Bransford, J. D., Ferrara, R. A. and Campione, J. C., (1983). Learning, Remembering and Understanding. In J. H. Flavell and M. Markman (Eds.), Carmichael's manual of child psychology (pp. 77-166). New York: Wiley.

Chen, Y. (2011). Study of the writing strategies used by Chinese non-English majors. Theory and Practice in Language Studies, 1(3), 245-251.

Chien, S. C. (2012). Students' use of writing strategies and their English writing achievements in Taiwan. The Asia Pacific Journal of Education, 32(1), 93-112.

Coe, N., \& Fowler, W. S. (1976). Nelson English language tests. London: Butler and Tanner Ltd.

Cohen, A.D., 1998. Strategies in learning and using a second language. Longman, London.

Dehghan, F. \& Razmjoo, S. A. (2012). Discipline-specific writing strategies used by TEFL graduate students. The Journal of Teaching Language Skills (JTLS), 4 (3), 1-22.

De Larios, J. R., Murphy, L., \& Manchon, R. (1999). The use of restructuring strategies in EFL writing: A study of Spanish learners of English as a foreign language. Journal of Second Language Writing, 8(1), 13-44.

De Silva, R. (2015). Writing strategy instruction: Its impact on writing in a second language for academic purposes. Language Teaching Research, 19(3), 301-323.

De Silva, R., \& Graham, S. (2015). The effects of strategy instruction on writing strategy use for students of different proficiency levels. System, 53, 47-59.

Eysenack, M. and Keane, M. (2005). Cognitive Psychology (5th edition), Hove: Psychology Press

Fahandezh, S. F., \& Othman, J. (2012). An investigation into writing strategies of Iranian EFL undergraduate learners. World Applied Sciences Journal, 18(8), 1148-1157.

Farhadi, H., Ja'farpur, A., \&Birjandi, P. (2010).Testing language skills: From theory to practice. Tehran: SAMT Publications.

Jacobs, H., Zinkgarfs, S., Warmuth, D., Hartfield, V., \& Hughey, J. (1981). Testing ESL composition: A practical approach. Rowley, Mass: Newbury House.

Hayes, J. R., \& Flower, L. S. (1980). Identifying the organisation of writing processes. In L. Gregg \& E. R. Steinberg (Eds.), Cognitive processes in writing (pp. 3-30). Hillsdale,NJ: Erlbaum.

Harris, K., Graham, S., Mason, L., \& Friedlander, B. (2008). Powerful writing strategies for 
all students. Baltimore, MD: Paul H. Brookes.

$\mathrm{Hu}$, G. (2005). Using peer review with Chinese ESL student writers. Language Teaching Research, 9(3), 321-342.

Kellogg, R.T. (1996). A model of working memory in writing. In C.M. Levy \& S. Ransdell (Eds.), The science of writing (pp. 57-72). Mahwah, NJ: Lawrence Erlbaum Associates.

Kiany, G. R. \& Movahedian, M. (2012). A comparative study of English education policies in Iran, China and Singapore, Quarterly Journal of Research on Issues of Education, 46(2), $25-57$.

Manchón, R. (Ed.) (2009). Writing in foreign language context: Learning, teaching and research. Bristol, UK: Multilingual Matters.

O’Malley, J. M., \& Chamot, A. U. (1990). Learning strategies in second language acquisition. Cambridge: Cambridge University Press.

Ong, J., \& Zhang, L. J. (2013). Effects of the manipulation of cognitive processes on EFL writers' text quality. TESOL Quarterly, 47(2), 375-398.

Oxford, R. (1990). Language learning strategies. Alabama: Newbury House Publishers.

Riazi, A. (1997). Acquiring disciplinary literacy: A social-cognitive analysis of text production and learning among Iranian graduate students of education. Journal of Second Language Writing, 6(2), 105-137.

Schunk, D., \& Zimmerman, B. (1997). Social origins of self-regulatory experience. Educational Psychologist, 32(4), 195-208.

Silva, T., \& Brice, C. (2004). Research in teaching writing. Annual Review of Applied Linguistics, 24, 70-106.

Thumpson, T., \& Simmon, N., (2009). Family and friends 3. United Kingdom: Oxford University Press

Yaghoubi, S. (2003). On the relationship between writing anxiety, writing strategies, and sentence complexity. Unpublished Master's Thesis, University of Tehran

Wong, R. M. F., \& Hew, K. F. (2010). The impact of blogging and scaffolding on primary school pupils' narrative writing: a case study. International Journal of Web-Based Learning and Teaching Technologies, 5, 1-17.

Zimmerman, B. J. (2000). Attaining self-regulation: A social cognitive perspective. In M.

Boekaerts, P. Pintrich, \& M. Zeidner (Eds.), Handbook of self-regulation (pp. 13-39). San Diego, CA: Academic Press. 


\section{Macrothink}

International Journal of Learning and Development

ISSN 2164-4063

\section{Copyright Disclaimer}

Copyright for this article is retained by the author(s), with first publication rights granted to the journal.

This is an open-access article distributed under the terms and conditions of the Creative Commons Attribution license (http://creativecommons.org/licenses/by/3.0/). 